\section{BORON DOPED DIAMOND FILMS SURFACE MODIFICATION WITH COPPER AND PALLADIUM NANOPARTICLES OBTAINED BY ELECTRODEPOSITION}

\author{
Jorge T. Matsushima $^{*}$, Valéria C. Fernandes, Glauber \\ Cruz, Adriana F. Azevedo, Maurício R. Baldan and \\ Neidenêi G. Ferreira
}

Instituto Nacional de Pesquisas Espaciais- INPE, São José dos Campos, 12.245-970, Brazil

*jtmatsushima@yahoo.com.br

Boron Doped Diamond (BDD) films, due its unique properties such as, wide potential working range with low background currents in aqueous and non-aqueous electrolytes and extreme physical and chemical stability that make them one of the most ideal electrode materials for electroanalysis and electrosynthesis [1]. Recently, several chemical species (organics and inorganics) have been analysed and destructed using this type of the material. Nevertheless, the comprehension of the electrochemical behavior has not yet been completely achieved, and many reports, including fundamental and technological aspects, have been published. Besides, the doping level, morphological features (grain boundaries and cristallographics defects) and non-diamond impurity content, the surface modification (surface group functionalities) is one of the factors which can heavily influence the electrochemical performance of BDD films [2]. The electrodeposition of metallic nanoparticles is an electrochemical procedure commonly used to carry out the surface modification. In this sense, this work proposes to study the BDD films surface modification with copper and palladium nanoparticles obtained by electrodeposition. The interest in this study is associated to their application as electrochemical sensor in the control of nitrate ions in wastewater. Particularly, the metallic particles electrodeposition, such as, copper and palladium may improve the BDD films electronalytical properties for nitrate ions detection due to their higher catalytic activity.

BDD films were grown on Si substrate by chemical vapor deposition (CVD) in a hot filament reactor during 6 hours. It was utilized a gaseous mixture of $99 \%$ vol. $\mathrm{H}_{2}$ and $1 \%$ vol. $\mathrm{CH}_{4}$ with a pressure of 50 torr. The boron doping was obtained from $\mathrm{H}_{2}$ forced to pass through a bubbler containing $\mathrm{B}_{2} \mathrm{O}_{3}$ dissolved in $\mathrm{CH}_{3} \mathrm{OH}$. The $\mathrm{H}_{2}$ and $\mathrm{B}_{2} \mathrm{O}_{3} / \mathrm{CH}_{3} \mathrm{OH} / \mathrm{H}_{2}$ were controlled in order to obtain the desired $\mathrm{B} / \mathrm{C}$ ratio in $\mathrm{CH}_{3} \mathrm{OH}$. From the Mott Schottky plot, the doping level was estimated to approximately $10^{20}$ boron atoms. $\mathrm{cm}^{-3}$ [3]. The electrochemical measurements were carried out using Autolab PGSTAT 302 equipment with a three-electrode cell. BDD films were used as a working electrode. A platinum wire serves as a counter electrode and $\mathrm{Ag} / \mathrm{AgCl}$ electrode was used as reference.

The Figures 1 and 2 show the cyclic voltammograms of the copper and palladium on BDD electrode. From cyclic voltammograms, surface modification due to metallic particles electrodeposition is evident, since the reduction and oxidation processes were observed. In the Figure 1, is verified the onset of copper deposition occurring approximately at $-0.1 \mathrm{~V}$. Afterwards, an increase in the cathodic current is observed, which is associated to copper crystallization process. However, in the reverse potential at $-0.4 \mathrm{~V}$, the current loop at $-0.32 \mathrm{~V}$ is attributed to copper deposition controlled by diffusion. Reversing the potential sweep to positive direction, approximately at
$0.0 \mathrm{~V}$, begins the copper dissolution process and two anodic processes were observed. The anodic peak at $0.15 \mathrm{~V}$ is associated with metallic copper dissolution, while the shoulder at $0.26 \mathrm{~V}$ may be related to hydrated copper oxide dissolution, possibly formed during the negative potential sweep. The Figure 2 shows the cyclic voltammograms of the palladium on BDD electrode. For onset potential sweep is observed an anodic current due to chloride oxidation. When the sweep reaches the potential of $0.15 \mathrm{~V}$ begin the palladium deposition. At $-0.85 \mathrm{~V}$, hydrogen evolution reaction is observed due to water reduction. Reversing the potential sweep to positive direction, several oxidation processes are observed. This behavior may be associated to dissolution of various intermetallic phases of palladium that probably were deposited during the deposition on the polycrystalline BDD surface. The electrodeposition results of copper and palladium showed a great possibility to obtain stable metallic particles on BDD surface and, consequently, to improve their electrocatalytic properties.

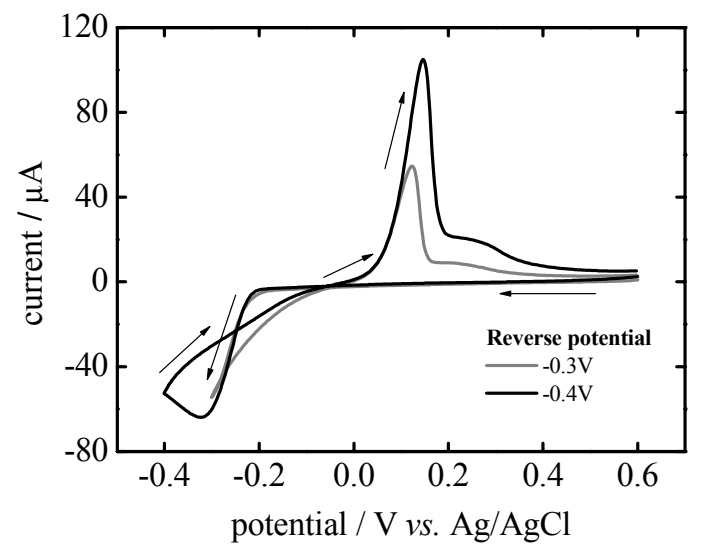

Figure 1: Cyclic voltammograms of the copper onto BDD electrode in $1 \times 10^{-3} \mathrm{~mol} \mathrm{~L}^{-1} \mathrm{CuSO}_{4}+0.1 \mathrm{~mol} \mathrm{~L}^{-1}$ solution for different reverse potential. Scan rate $=50 \mathrm{mV} \mathrm{s}^{-1}$

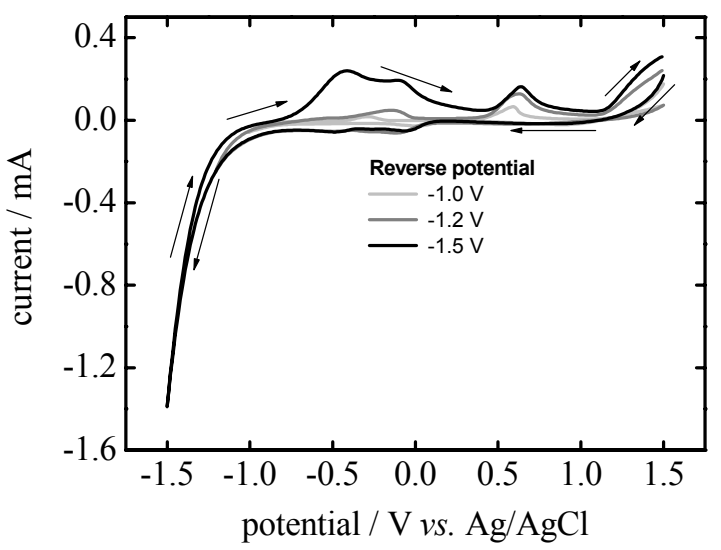

Figure 2: Cyclic voltammograms of the palladium onto $B D D$ electrode in $1 \times 10^{-3} \mathrm{~mol} \mathrm{~L}^{-1} \mathrm{PdCl}_{2}+0.05 \mathrm{~mol} \mathrm{~L}^{-1} \mathrm{KCl}$ solution for different reverse potential. Scan rate $50 \mathrm{mVs}^{-1}$

We are so grateful to Fapesp and CNPq for financial support.

[1] G.M. Swain, in: A.J. Bard, I. Rubinstein (Eds.), Electroanalytical Chemistry, vol. 22, M. Dekker, N.Y., 2004.

[2] I. Duo, A. Fujishima, C. Comninellis, Electrochem. Commun. 5 (2003) 695.

[3] N.G. Ferreira, L.L.G. Silva, E.J. Corat, V.J. Trava Airoldi, K. Iha Braz J Phys, 29 (1999) 760. 